\title{
PENGARUH TERAK SEBAGAI PENGGANTI AGREGAT KASAR TERHADAP KUAT TEKAN DAN BERAT JENIS PADA BETON NORMAL
}

\author{
Ida Nugroho Saputro, Anis Rahmawati, Wahyu Indri Satupi \\ Pendidikan Teknik Bangunan Fakultas Keguruan dan Ilmu Pendidikan \\ Universitas Sebelas Maret Surkarta \\ Email : nugroho.saputro@yahoo.co.id
}

\begin{abstract}
ABSTRAK
Metode yang di gunakan pada penelitian ini adalah metode eksperimen, yaitu mengadakan suatu percobaan untuk mendapatkan suatu hasil yang menegaskan hubungan antara variabel-variabel yang di selidiki. Variabel yang mempengaruhi langsung dalam penelitian ini adalah Variabel bebas dan variabel terikat. Variabel bebas adalah variasi terak yang digunakan sebagai pengganti agregat kasar yaitu dengan variasi prosentase sebesar $0 \%$, $10 \%, 20 \%, 30 \%, 40 \%, 60 \%, 80 \%$ dan $100 \%$ dengan rencana campuran menggunakan Mix Design berdasarkan pada SK SNI 03-2847-2002, sedangkan variabel terikatnya adalah berat jenis dan kuat tekan beton. Berdasarkan hasil penelitian dapat di peroleh prosentase penggantian terak yang optimal sebesar 39,986 \% dengan kekuatan tekan maksimal sebesar 22,626 MPa. Pengaruh terak sebagai pengganti agregat kasar berpengaruh secara signifikan terhadap kuat tekan beton. Dimana dapat dilihat pada hasil analisis regresi dengan Curve Estimation model Linier, Quadratic diperoleh nilai probabilitas 0,001 $(<0,05)$ pada taraf signifikansi 5\%. Penggantian terak sebagai pengganti agregat kasar berpengaruh sangat kuat terhadap berat jenis beton. Pada hasil uji berat jenis menunjukkan bahwa semakin banyak penggunaan terak, mengakibatkan semakin tinggi nilai berat jenis beton. Variasi terak sebagai pengganti agregat kasar menghasilkan berat jenis beton normal pada prosentase $0 \%$, $10 \%, 20 \%$, sedangkan pada prosentase 30\%, 40\%, 60\%, 80\%, 100\% menghasilkan berat jenis yang tidak masuk dalam kriteria berat jenis beton normal $\left(>2400 \mathrm{~kg} / \mathrm{m}^{3}\right)$. Berat jenis beton normal $2300 \mathrm{~kg} / \mathrm{m}^{3}-2400 \mathrm{~kg} / \mathrm{m}^{3}$ (Tjokrodimuljo, 2004). Simpulan penelitian ini adalah variasi terak sebagai pengganti agregat kasar berpengaruh secara signifikan terhadap kuat tekan beton dan berpengaruh sangat kuat terhadap berat jenis beton sehingga dapat digunakan dalam struktur bangunan.
\end{abstract}

Kata Kunci: terak, kuat tekan, berat jenis, beton

\section{PENDAHULUAN}

Negara Indonesia adalah suatu negara yang padat penduduknya. Laju pertumbuhan penduduk di Indonesia yang semakin tinggi berakibat pada tingginya permintaan kebutuhan akan pembangunan rumah tinggal atau pemukiman, karena rumah tinggal merupakan kebutuhan pokok yang harus dipenuhi oleh manusia. Beton merupakan bahan konstruksi yang sangat penting dan

JIPTEK, Vol. VII No. 1, Januari 2014 paling dominan digunakan pada struktur bangunan. Pengetahuan tentang beton telah sangat luas dan sudah banyak diketahui, baik mengenai sifat bahan dasar maupun cara pembuatannya. Beton adalah bahan bangunan yang diperoleh dengan cara mencampurkan semen Portland, air, agregat (baik agregat halus dan agregat kasar) seperti yang umum diketahui merupakan faktor utama yang mempengaruhi besarnya berat 
jenis beton, maka agar beton diartikan telalb. Tahap Penelitian Penelitian

luas penggunaannya dan dikembangkan menjadi beton ramah lingkungan diupayakan menggunakan bahan jenis lain dengan memanfaatkan limbah atau sampah yang ada disekitar kita sebagai alternatif bahan pengganti agregat normal dengan agregat yang lain yang masih mempunyai sifat yang sama. Salah satu contoh sampah atau limbah yang dimanfaatkan dengan baik adalah limbah industri pengecoran.

Tujuan dari penelitian ini adalah untuk mengetahui pengaruh penggantian terak dengan agregat kasar terhadap kuat tekan beton, untuk mengetahui pengaruh penggantian terak terhadap berat jenis beton, untuk mengetahui prosentase optimal terak yang digunakan sebagai pengganti agregat kasar, untuk mengetahui prosentase terak yang digunakan sebagai pengganti agregat kasar untuk mencapai berat jenis beton normal.

\section{METODE PENELITIAN}

a. Sampel penelitian

Sampel dalam penelitian dapat dijelas dengan tabel berikut:

Tabel 1. Jumlah Keseluruhan Sampel Beton

\begin{tabular}{ccc}
\hline No & $\begin{array}{c}\text { Prosentase } \\
\text { terak }\end{array}$ & Jumlah sampel beton \\
\hline 1 & $0 \%$ & 5 buah \\
2 & $10 \%$ & 5 buah \\
3 & $20 \%$ & 5 buah \\
4 & $30 \%$ & 5 buah \\
5 & $40 \%$ & 5 buah \\
6 & $60 \%$ & 5 buah \\
7 & $80 \%$ & 5 buah \\
8 & $100 \%$ & 5 buah \\
\hline & Total sampel $=$ & 40 buah \\
\hline
\end{tabular}

JIPTEK, Vol. VII No. 1, Januari 2014
1) Penelitihan ini meliputi beberapa tahap yaitu:
a) Tahap I : Persiapan alat dan bahan
b) Tahap II : Pemeriksaan bahan (pasir, kerikil dan terak)
c) Tahap III :Pembuatan sampel beton dengan metode campuran mix design
d) Tahap IV : Perawatan beton
e) Tahap V : Pengujian beton (kuat tekan dan berat jenis)
f) Tahap VI : Analisis data
g) Tahap VII : Kesimpulan

2) Alur pembuatan beton meliputi persiapan bahan, pemasukan bahan kedalam mesin pengaduk (molen), pencetakan beton kedalam silinder ukuran $30 \mathrm{~cm}$ x $15 \mathrm{~cm}$, pengeringan selama 24 jam, perawatan beton selama 28 hari, pengujian kuat tekan dan berat jenis beton.

3) Teknik Analisis Data

Teknik analisis data yang dipakai dalam penelitian ini yaitu analisis regresi, yang sebelumnya diuji prasyarat analisis terlebih dahulu yaitu uji normalitas dan uji linieritas.

\section{HASIL DAN PEMBAHASAN}

a. Hasil Pemeriksaan Bahan

Tabel 2. Rekapitulasi Hasil Pengujian Agregat Halus

\begin{tabular}{c|c|c|c}
\hline Parameter & Hasil & Stándar & Keterangan \\
\hline $\begin{array}{c}\text { Kadar } \\
\text { lumpur }\end{array}$ & $4,2 \%$ & $<5 \%$ & memenuhi \\
\hline $\begin{array}{c}\text { Kandungan } \\
\text { zat organik }\end{array}$ & $\begin{array}{c}\text { kuning } \\
\text { kemerahan }\end{array}$ & $\begin{array}{c}\text { Jernih- } \\
\text { coklat }\end{array}$ & \\
\hline $\begin{array}{c}\text { Bulk } \\
\text { specific } \\
\text { gravity } \\
\text { (SSD) }\end{array}$ & 2,45 & memenuhi \\
\hline Absorbsi & $3,62 \%$ & - & - \\
\hline Modulus & 2,71 & - & - \\
\hline
\end{tabular}




\begin{tabular}{c|c|c|c}
\hline kehalusan & & & \\
\hline Kadar air & $2,63 \%$ & $2,3-$ & memenuhi \\
& & 3,1 & memenuhi \\
& & $1 \%-3 \%$ & \\
\hline
\end{tabular}

Dari tabel 2. dapat di lihat bahwa hasil pemeriksaan agrerat halus telah memenuhi ketentuan yang sudah menjadi standart dari tiap-tiap pemeriksaan agregat halus sehingga agregat halus yang ada dapat di gunakan untuk pembuatan sampel atau benda uji beton. Pengujian yang terakhir yaitu uji gradasi pasir, hasil pengujian pasir yang dilakukan peniliti sudah masuk dalam persyaratan yaitu termasuk dalam daerah II.

Tabel 3. Rekapitulasi Hasil Pengujian Agregat Kasar

\begin{tabular}{|c|c|c|c|}
\hline $\begin{array}{c}\text { Paramet } \\
\text { er }\end{array}$ & Hasil & Estándar & Keterangan \\
\hline $\begin{array}{l}\text { Modulus } \\
\text { kehalusan } \\
\text { terak }\end{array}$ & 7,99 & $6-10$ & Memenuhi \\
\hline Abrasi terak & $\begin{array}{c}60,86 \\
\%\end{array}$ & $50 \%$ & $\begin{array}{c}\text { Tidak } \\
\text { memenuhi }\end{array}$ \\
\hline $\begin{array}{l}\text { Bulk } \\
\text { specific } \\
\text { gravity } \\
\text { (SSD) terak }\end{array}$ & 2,78 & $2,7-3,2$ & Memenuhi \\
\hline $\begin{array}{l}\text { Modulus } \\
\text { kehalusan } \\
\text { kerikil }\end{array}$ & 8,11 & & Memenuhi \\
\hline $\begin{array}{l}\text { Abrasi } \\
\text { kerikil }\end{array}$ & $\begin{array}{c}46,9 \\
\%\end{array}$ & $6-10$ & Memenuhi \\
\hline $\begin{array}{l}\text { Bulk } \\
\text { specific } \\
\text { gravity } \\
\text { (SSD) } \\
\text { kerikil }\end{array}$ & 2,4 & $\begin{array}{c}<50 \% \\
-\end{array}$ & - \\
\hline
\end{tabular}

Dari tabel 3 dapat di lihat bahwa hasil pemeriksaan abrasi terak tidak memenuhi standar karena permukaan terak yang berongga sehingga terak mudah pecah. Sedangkan pada pemeriksaan modulus kehalusan, bulk specific grafity telah memenuhi ketentuan yang sudah menjadi standart dari tiap-tiap pemeriksaan agregat kasar sehingga agregat kasar yang ada dapat di gunakan untuk pembuatan sampel atau benda uji beton.

b. Hasil Pengujian Kuat tekan Beton

Hasil pengujian kuat tekan beton ini dilakukan pada beton dengan persentase $0 \%$, yang menghasilkan rerata kuat tekan sebesar 20,50 $\mathrm{MPa}$, prosentase $10 \%$ menghasilkan rerata kuat tekan sebesar 21,12 $\mathrm{MPa}$, prosentase 20\% menghasilkan rerata kuat tekan sebesar 22,02 $\mathrm{MPa}, \quad$ prosentase $30 \%$ menghasilkan rerata kuat tekan sebesar 22,48 $\mathrm{MPa}$, prosentase $40 \%$ menghasilkan rerata kuat tekan sebesar 22,65 $\mathrm{MPa}$, prosentase $60 \%$ menghasilkan rerata kuat tekan sebesar 23,33 $\mathrm{MPa}$, prosentase $80 \%$ menghasilkan rerata kuat tekan sebesar 20,89 $\mathrm{MPa}$, sedangkan pada prosentase $100 \%$ menghasilkan rerata kuat tekan sebesar 21,74 MPa.

c. Pembahasan

1) Pembahasan Kuat Tekan Beton

a) Pengaruh Terak Sebagai Pengganti Agregat Kasar Terhadap Kuat Tekan Beton Hasil output SPSS untuk variasi penggantian terak sebagai agregat kasar ketika input di gunakan value atau label yakni 1 untuk 0\%, 2 untuk 10\%, 3 untuk 20\%, 4 untuk 30\%, 5 untuk 40\%, 6 untuk $60 \%, 7$ untuk $80 \%, 8$ untuk $100 \%$.

Hasil pengujian hipotesis kesatu dengan analisis regression curve estimation, model linier dan quadratic dapat diketahui $\mathrm{R}$ square sebesar 0,313 adalah (angka pengkuadratan dari 0,56 $\mathrm{x}$ $0,56)$ yang artinya bahwa nilai $R$ yang mendekati $0,40-0,599$ 
mempunyai tingkat hubungan yang sedang antara variabel $\mathrm{X}$ terhadap variabel Y. Maka dapat disimpulkan penggantian agregat kasar dengan terak berpengaruh sedang terhadap kuat tekan beton. Untuk mengetahui variasi optimum penggantian terak sebagai agregat kasar yang menghasilkan beton dengan kekuatan maksimum dari hasil perhitungan program SPSS mendapatkan persamaan regresi adalah :

$\mathrm{Y}=-0,143 \mathrm{X}^{2}+1,426 \mathrm{X}+$ 19,071

Dimana :

$\mathrm{X}=$ variasi penggantian agregat kasar dengan terak.

$\mathrm{Y}=$ kuat tekan

Terdapat kuat tekan beton maksimal pada prosentase penggantian terak tertentu. Nilai $\mathrm{X}$ pada persamaan regresi tersebut dapat dihitung dengan rumus sebagai berikut:

$Y=-0,143 X^{2}+1,426 X+19,071$

$$
\frac{d y}{d x}=0
$$

Dimana : $\mathrm{a}=-0,143$

$\mathrm{b}=$

$1,426 \quad c=19,071$

Sehingga:

$0=2 .-0,143 x+1,426+0$

$\mathrm{x}=4,986$

nilai $\mathrm{X}$ yang di peroleh masuk ke persamaan:

$Y=-0,143 X^{2}+1,426 X+19,071$

$\mathrm{Y}=-0,143(4,986)+1,426$

$(4,986)+19,071$

$\mathrm{Y}=22,626 \mathrm{Mpa}$

Dari perhitungan di atas dapat disimpulkan prosentase penggantiaan terak yang optimum untuk mencapai kuat tekan beton yang maksimum sebesar $39,986 \%$, pada prosentase penggantian tersebut akan diperoleh kuat tekan beton sebesar 22,626 MPa.

d. Hasil Pengujian Berat Jenis Beton

Tabel 4. Hasil Pemeriksaan Berat Jenis Beton Dengan Variasi Penggantian

Agregat Kasar Dengan Terak

\begin{tabular}{cccc}
\hline $\begin{array}{c}\text { Kode } \\
\text { No }\end{array}$ & $\begin{array}{c}\text { prosentase } \\
\text { terak } \\
(\%)\end{array}$ & $\begin{array}{c}\text { Berat } \\
\text { Jenis } \\
(\mathrm{kg} / \mathrm{m} 3)\end{array}$ & $\begin{array}{c}\text { Berat Jenis } \\
\text { Beton } \\
\text { Rata-Rata }\end{array}$ \\
\hline 1 & & 2355,76 &
\end{tabular}

\begin{tabular}{ccccc} 
& 2 & & 2347,84 & \\
B.0 & 3 & $0 \%$ & 2351,65 & 2332,55 \\
& 4 & & 2329,06 & \\
& 5 & & 2278,46 & \\
\hline 1 & & 2396,00 & \\
& 2344,31 &
\end{tabular}

BT 10

2347,97

$3 \quad 10 \% \quad 2359,78$

$4 \quad 2369,50$

52270,23

1

2338,66

22376,47

B.T 20

$20 \%$

2341,27

2356,66

4

2362,54

\begin{tabular}{lll}
5 & & 2364,35 \\
\hline 1 & $30 \%$ & 2421,65 \\
2 & & 2391,79
\end{tabular}




\begin{tabular}{|c|c|c|c|}
\hline \multicolumn{2}{|l|}{ B.T 30} & & \multirow[t]{4}{*}{2401,75} \\
\hline 3 & & 2359,27 & \\
\hline 4 & & 2429,42 & \\
\hline 5 & & 2406,61 & \\
\hline \multirow{4}{*}{$\begin{array}{r}\text { BT } 40 \\
3\end{array}$} & \multirow{6}{*}{$40 \%$} & 2429,63 & \multirow{6}{*}{2430,90} \\
\hline & & 2434,69 & \\
\hline & & & \\
\hline & & 2449,28 & \\
\hline 4 & & 2412,02 & \\
\hline 5 & & 2428,89 & \\
\hline \multirow{4}{*}{$\begin{array}{r}\text { B.T } 60 \\
3\end{array}$} & \multirow{6}{*}{$60 \%$} & 2466,92 & \multirow{6}{*}{2447,28} \\
\hline & & 2467,54 & \\
\hline & & & \\
\hline & & 2413,87 & \\
\hline 4 & & 2456,49 & \\
\hline 5 & & 2431,57 & \\
\hline \multirow[b]{3}{*}{$\begin{array}{r}\text { B.T } 80 \\
3\end{array}$} & \multirow{5}{*}{$80 \%$} & 2432,80 & \multirow{5}{*}{2454,51} \\
\hline & & 2470,60 & \\
\hline & & 2448,95 & \\
\hline 4 & & 2467,56 & \\
\hline 5 & & 2452,64 & \\
\hline \multirow[b]{3}{*}{$\begin{array}{r}\text { B.T100 } \\
3\end{array}$} & \multirow{5}{*}{$100 \%$} & 2530,99 & \multirow{5}{*}{2500,40} \\
\hline & & 2553,96 & \\
\hline & & 2408,25 & \\
\hline 4 & & 2524,22 & \\
\hline 5 & & 2484,57 & \\
\hline
\end{tabular}

e. Pembahasan

Pengaruh terak sebagai pengganti agregat kasar terhadap berat jenis beton. Pengujian hipotesis ini menggunakan program SPSS 16 dengan menggunakan uji Regression curve estimation, mode linear dan quadratic dapat diketahui penggantian terak sebagai agregat kasar berpengaruh secara signifikan terhadap berat jenis beton. Hal ini dapat dibuktikan bahwa nilai $\mathrm{R}$ square sebesar 0,761 ( angka pengkuadratan dari 0,872x0,872). Sedangkan berdasarkan hasil analistis deskriptif, diperoleh hasil seperti ditampilkan dalam diagram pada Gambar 1 berikut ini:

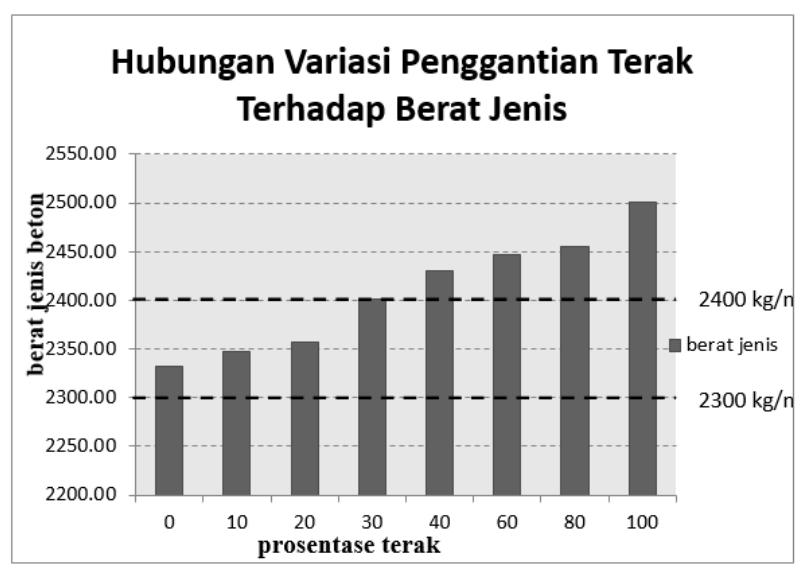

Gambar 1. Hubungan Variasi Penggantian Terak Terhadap Berat Jenis

Berdasarkan gambar 1 terlihat bahwa berat jenis beton semakin meningkat, pada prosentase penggantian terak sebagai agregat kasar sebesar 0\%, 10\%, 20\% hasil berat jenis rata-rata memenuhi kriteria berat jenis beton normal yaitu $<2400 \mathrm{~kg} / \mathrm{m}^{3}$, sedangkan pada prosentase $30 \%, 40 \%, 60 \%$, $80 \%$ dan $100 \%$ mengalami kenaikan dan berat jenis beton melebihi dari kriteria berat jenis beton normal yaitu $>2400 \mathrm{~kg} / \mathrm{m}^{3}$ (dapat dilihat pada gambar 4.1 diatas) dan tidak termasuk kategori dalam berat jenis beton normal karena terbukti berat jenis terak lebih besar dari berat jenis agregat kasar normal (2,78 > 2,47), jadi dapat di simpulkan bahwa 
semakin banyak terak yang digunakan semakin tinggi berat jenis beton. Berat jenis beton normal berkisar $2300 \mathrm{~kg} / \mathrm{m}^{3}$ sampai $2400 \mathrm{~kg} / \mathrm{m}^{3}$ (Tjokrodimulyo. 2004)

\section{KESIMPULAN}

Berdasarkan hasil analisis data dan pembahasan dapat diambil kesimpulan sebagai berikut:

1) Ada pengaruh variasi penggantian terak sebagai agregat kasar terhadap kuat tekan beton yang sedang antara variasi penggantian terak sebagai agregat kasar atau penggantian terak sebagai agregat kasar berpengaruh secara signifikan terhadap kuat tekan beton Pengaruh yang terjadi bersifat positif, dimana penggantian terak sebagai agregat kasar akan mengakibatkan peningkatan kuat tekan beton.

2) Ada pengaruh variasi penggantian terak sebagai agregat kasar terhadap berat jenis beton yang sangat kuat antara variasi penggantian terak sebagai agregat kasar atau penggantian terak sebagai agregat kasar berpengaruh secara signifikan terhadap berat jenis beton. Pengaruh yang terjadi bersifat positif, dimana penggantian terak sebagai agregat kasar akan mengakibatkan peningkatan berat jenis beton.

3) Penambahan terak optimal untuk beton normal sebesar 39,986\% dengan kuat tekan sebesar 22,626 MPa.

4) Pada hasil uji berat jenis menunjukkan bahwa semakin banyak penggunaan terak, mengakibatkan semakin tinggi berat jenis beton. Dari berbagai variasi penggantian terak sebagai agregat kasar yang digunakan pada penelitian ini berat jenis ada yang memenuhi syarat beton dengan berat jenis beton normal pada prosentase $0 \%, 10 \%, 20 \%$. Berat jenis beton normal yakni $2300 \mathrm{~kg} / \mathrm{m}^{3}-2400 \mathrm{~kg} / \mathrm{m}^{3}$ Tjokrodimuljo, (2004). Sedangkan untuk prosentase $30 \%, 40 \%, 60 \%, 80 \%$ dan $100 \%$ tidak masuk dalam kategori beton normal $\left(>2400 \mathrm{~kg} / \mathrm{m}^{3}\right)$

\section{DAFTAR PUSTAKA}

C. Trihendradi. (2011) . Langkah-Langkah Mudah melakukan Analisis Stasistik menggunakan SPSS 19. Yogyakarta : CV. Andi Offset.

Handayani. (2008). Pemanfaatan Limbah Industri Cor Logam (klelet) Batur untuk Beton Kedap Air. Skripsi Teknik Sipil. Universitas Muhammadiyah Surakarta

Hartono. (2010). SPSS 16.0 Analisa Data Statistik dan Penelitian. Yogyakarta : Pustaka Belajar.

Heinz Frick dan Ch. Koesmartadi. (1999). Ilmu Bahan Bangunan. Yogyakarta : Kanisius.

Isah Iriawan. (2012). Pengaruh Penambahan Terak terhadap Kuat Tekan Paving Block. Skripsi Pendidikan Teknik Sipil. Universitas Sebelas Maret

Litbang. (2002). Beton SNI 03-2847-2002.

L.J. Murdock dan K.M. Brook. (1986). Bahan dan Praktek Beton. Jakarta : Erlangga.

Mulyono, T. (2003). Teknologi Beton. Yogyakarta : CV. Andi Offset.

Paul Nograha dan Antoni, (2007). Teknologi Beton dari Material, Pembuatan, Beton Kinerja Tinggi, Yogyakarta: Andi.

Rina Rahmiati L. (2010). Pembuatan Beton Kedap Air Dengan Memanfaatkan Klelet Sebagai Pengganti Agregat. Skripsi Teknik Sipil. Universitas Muhammadiyah Surakarta 
Sagel. R dan Kole. P (Terjemahan Gideon Kusuma). (1997). Pedoman Pengerjaan Beton (Berdasar SK SNI T- 15- 1991- 03), Jakarta: Erlangga.

Samekto, W. dan Candra, R. (2001). Teknologi Beton. Yogyakarta: Kanisius

Saptahari Sugiri. (2005). Kandungan Terak Logam. Jurnal Infrastruktur dan Lingkungan Binaan. Departemen Teknik Sipil ITB.

Sjafe amri. (2005). Teknologi Beton A-Z. Jakarta : Yayasan John Hi-Tech Idetama.

Sudjana. (2002). Metode Statistik . Bandung : Tarsito.

Sugiyono. (2006). Statistik Untuk Penelitian. Bandung : Alfabeta

Tjokrodimuljo, K. (2004). Teknologi Beton, Jurusan Teknik Sipil, Fakultas Teknik Universitas Gadjah Mada, Yogyakarta.

Widiyanto,J. (2011). SPSS For Windows. Surakarta: Laboratorium Komputer FKIP Universitas Sebelas Maret. 